\title{
Communicating In A Multicultural Classroom: A Study Of Students' Nonverbal Behavior And Attitudes Toward Faculty Attire
}

Ephraim Okoro, Howard University, USA

Melvin Washington, Howard University, USA

\begin{abstract}
Economic and market globalization in the United States has engendered a multicultural learning environment that challenges both faculty and students. Diversity in the classroom is further complicated by nonverbal communication, which impacts on students' attitudes toward faculty members. Because today's classrooms are changing and undergoing rapid shifts in composition, culture, and orientation, the nature of learning is also changing to be more participative, interactive, and team-oriented. To ensure that effective learning is taking place in global/multicultural classroom settings, an improved faculty-student nonverbal relationship is critically important. This study, therefore, emphasizes the importance of appropriate dress/attire in a diverse classroom setting.
\end{abstract}

Keywords: nonverbal communication; faculty; student; multicultural classrooms; globalization; attire

\section{INTRODUCTION}

$\mathrm{n}$ the wake of globalization, educators and researchers are re-examining the quality of faculty-students e relationships and are placing increasing emphasis on nonverbal communication in classrooms because of its impact on student perceptions in the learning environment. This trend has been necessitated by the diversity of student and faculty population in higher education. Many faculty and students come from different cultural backgrounds and nationalities and their communication patterns are unique, especially their nonverbal symbols and cues. According to Samovar \& Porter (1997), building rapport with students from diverse cultures and effectively interacting with them requires a combination of understandable nonverbal and verbal elements of communication. Nonverbal communication (e.g., dress/attire, facial expression, gestures, paralinguistics, proxemics, tone of voice, eye gaze, haptics, etc.) differs among cultures and has often been subjected to a wide range of interpretation. A number of recent studies on intercultural and nonverbal communication indicate that a substantial portion of human interaction has been nonverbal (Barna, 1997; Jandit, 2001; James \& Devlin, 2001). Independently, these studies emphasize that from dress/attire, and handshakes to hairstyles, nonverbal elements demonstrate who we are and affect our relationship with others. In other words, an individual's personality (i.e., self-esteem and self-concept) can be revealed by nonverbal actions.

\section{LITERATURE REVIEW}

Over the past few years, there has been considerable discussion in the academic literature regarding faculty members' dress/attire in the classroom. This debate has been significant to researchers because of the global and multicultural nature of today's learning environment. Students from different cultural backgrounds should be able to communicate effectively with their professors, both verbally and nonverbally, in order for learning to occur. However, communication experts point out that nonverbal communications (e.g., facial expression, gestures, body 
language and posture, dress/attire, etc.) have a significant impact on students' attitudes toward their relationship with faculty (Rollman, 1990; Scott, J, \& Cheatham, 1994). Faculty members make lasting impressions on their students through their appearance, specifically their dress/attire, which contributes largely to a positive or negative perception (Hall, A. \& Berardino, 2006). Around the world, there have been ongoing discussions as to whether faculty members should wear business attire to their campuses in order to represent themselves as professionals (Molloy, 1975; Rafaeli \& Pratt, 1993). Many of today's classroom settings have a global presence, multicultural interpretations, and a student-faculty relationship that is shaped by nonverbal exchange. Business or professional dress/attire by faculty members gives the impression that they are proud of their professions, which ultimately affects students' views of them (Chaney \& Martin, 2007).

Some students come from countries where professional or appropriate attire is required of faculty in order to enhance the image of the teaching profession. Additionally, business attire distinguishes faculty and students at many university campuses. As Elrod (2006) noted, faculty members should be paid and treated as professionals and they should be required to dress properly in a manner that attracts the respect of their students. The author noted that in an era where students are not taking education too seriously, it would be compounded by faculty who enter their classrooms dressed as if they are going to the beach or working in their yards. Organizational researchers noted that a substantial portion of business communication is nonverbal and that dress/attire plays a significant role in the establishment of relationships between supervisors and subordinates in the workplaces and between faculty and students in the classrooms (Check, 2001; Bassett, 1979).

In the twenty-first century educational environment, the classroom is more than a place where knowledge, skills, and competencies are taught and shared. It is a miniature community in itself where students and faculty interact, exchange their ideas and cultures, and influence the behavior of one another. The quality of learning, the structure of interactions, and the nature of influences in the classrooms are critically important and instrumental in forming students' perceptions and attitude towards their faculty and instructional content (Chaney \& Martin, 2007). Furthermore, studies (Malloy, 1977; Elrdo, 2006; and Cardon \& Okoro, 2010) indicate that faculty members engage in interactive behavior with students in the classroom for the purpose of transmitting knowledge or effecting change in the students' character or disposition. Indeed, educators create favorable impressions on students or learners by presenting themselves in professional or appropriate attire. A number of positive and effective characteristics of members of faculty seem to be consistent with Maslow's conceptualization of the self-actualizing person, whom he sees as fully functioning and possessing such attributes as acceptance, autonomy, democratic and cosmopolitan nature, creativeness, and effective communication. As Maslow (1970) explains, the self-actualizing individual could be considered the most productive faculty. In his study on the importance of teacher/faculty personality, Molloy (1975) explains that faculty members play a critical role in the learning process. Therefore, personality reflected through dress and attire positively or negatively impacts faculty-student relationships in the classroom and creates a lasting impression for the students.

Additionally, faculty members' ability to transmit knowledge, as well as to influence students in the classroom, is a function of both verbal and nonverbally communication. As Mehrabian (1968) states, less than 10\% of a message is sent through words, and when verbal and nonverbal messages conflict, the latter tends to prevail. The pedagogical activities of faculty and their nonverbal messages (i.e., dress/attire) combine to make the learning experience exciting and create a lasting impression (Zweifel, 2003). Indeed, actions and nonverbal communication have a greater effect than verbal communication, especially in a diverse classroom. Faculty members should not only place emphasis on their instructional quality and content, but put priority on their critical nonverbal content (Scott; O'Neal, \& Cheatham, 1994). Because of its significance, the dress/attire aspect of nonverbal communication has been of immense interest to researchers for some time now. According to Morris (1977), much of the dress/attire research has been conducted in the social sciences (e.g., communication, psychology, sociology, and economics). Additionally, Molloy $(1975 ;$ 1977) explains that clothing/attire is a nonverbal communication that reveals an individual's educational level, social position, economic background, and social background, and it impacts people's (i.e., students) judgments of credibility, likeability, and interpersonal attractiveness.

A number of studies have been conducted on varying dimensions of dress/attire in academic settings. In several cases, photographs of professors were used to gather and evaluate observations, while in others, live models were utilized. Specifically, studies of the effects of attire/clothing on observer perceptions have shown that formal or 
professional dress is positively perceived, both in academic and business settings (Harris et al., 1983; Bassett, 1979. As Cardon and Okoro (2009) stressed, employees (including faculty members) are advised to dress for success to build their careers. They explain that surveys of employers consistently illustrate the importance of dressing up in many organizations, including academic institutions. For example, $41 \%$ of employers stated that employees who dressed more professionally were more likely to be promoted. Furthermore, recent studies describe the long-lasting impressions formed by professional attire and appearance. Stressing the significance of appropriate attire in the workplace, Wasley (2007) pointed out that the administrators at Tri-State University in Indiana reinforced the rules requiring faculty and staff members to present themselves professionally and to conform to workplace dress codes at all times. It was no longer acceptable for any faculty or staff to come on campus dressed inappropriately. For example, male faculty members were required to wear ties and dress shirts, tucked in, with business or dress khakis; and, if the slacks had belt loops, a belt must be worn. Hair was to be kept trimmed above the ears, any facial hairs had to be well manicured, and the wearing of earring was prohibited in the classrooms.

\section{SIGNIFICANCE OF THE STUDY}

This research is important because it offers a candid view of how nonverbal communication theory is realized in both business and classroom settings. Although it is not thought of as an element of etiquette, one's personal appearance in the workplace sends a strong signal to managers, colleagues, and customers (Bovee \& Thill, 2008). Many times, a person's response to messages, such as those found in student-to-faculty relationships, is dependent on their personal appearance. In order to teach effectively, an instructor must have the attention of the student. The more tools that can be added to the teaching arsenal, the better the chance that the instructional effort will be a success (Wilson, 2000). However, while dressing for success has been a long-standing concept in Western society, the importance of nonverbal communication has accelerated with increasing globalization and diversity within today's classroom. The interaction of culture and communication is so pervasive that separating the two is virtually impossible (Slethaung, 2007). Oftentimes, prejudice is based on nonverbal aspects of behavior. That is, the negative prejudgment is triggered by physical appearances or behavior (Martin \& Nakayama, 2007). Therefore, it is essential that university faculty become aware of the increasing influence that nonverbal behaviors have on student perceptions.

\section{METHOD}

This study was conducted in the spring of 2010 in the School of Business of a mid-size historically Black college and university in the Eastern region of the United States. The researchers' primary focus was conducting nonverbal communication research on student perceptions of faculty dress/attire in the classroom within a culturally diverse faculty and student population. Prior studies suggest that perceptions are valid indicators of what happens in the classroom (Rubin, Palmgreen \& Sypher, 1994).

Students in the university's School of Business were given the opportunity to participate in the survey. The purpose of the survey was to assess the impact of the faculty's dress/attire on the students' perceptions of faculty members' performance and professionalism. The survey was administered on a strictly voluntary basis during the regular class times of the respondents. The respondents received extra credit points for their participation. The survey was given in classes within multiple disciplines and grade levels in an effort to capture a range of both culture and age. The questionnaires were administered by graduate assistants during the normal class hours of the respondents. Two hundred forty-three (243) respondents were surveyed with 204 usable surveys being completed - a response rate of $84 \%$.

The survey questions were modified from the work of Carr (2006) on the effects of business faculty attire on the quality of instruction. The specific questions were based on the following areas:

- $\quad$ Faculty members' level of preparation

- $\quad$ Faculty members' knowledge of subject matter

- $\quad$ Faculty members' ability to prepare students for a business career

- $\quad$ Faculty members' level of credibility

- $\quad$ Faculty members' ability to communicate 
- $\quad$ Faculty members' overall performance

- $\quad$ Faculty members' enthusiasm for teaching

- $\quad$ Faculty members' concern for the students

- $\quad$ Faculty members' level of professionalism

- $\quad$ Faculty members' level of expertise

Hence, the focus of this research attempts to answer the following research questions:

- $\quad$ To what degree do university students adopt attitudes towards faculty attire in globally diverse classroom settings?

- How does age influence students' attitudes toward faculty attire in globally in diverse classroom settings?

- How does gender influence students' attitudes toward faculty attire in globally diverse classroom settings?

- How does culture influence students' attitudes toward faculty attire in globally diverse classroom settings?

A total of 204 students completed the surveys. Demographic characteristics of the survey respondents are listed in Table 1.

Table 1: Demographic Information Of Survey Respondents

\begin{tabular}{|l|l|l|}
\hline & $\mathbf{n}$ & $\mathbf{\%}$ \\
\hline Gender & & \\
\hline Male & 93 & $45.01 \%$ \\
\hline Female & 111 & $54.04 \%$ \\
\hline Birthplace & & \\
\hline USA & 148 & $72 \%$ \\
\hline Outside the USA & 56 & $28 \%$ \\
\hline Age & & \\
\hline 17 yrs to 29 yrs & 170 & $83.03 \%$ \\
\hline 30 yrs to 39 yrs & 28 & $13.07 \%$ \\
\hline 40 yrs to 49 yrs & 6 & $2.09 \%$ \\
\hline
\end{tabular}

\section{RESULTS}

Tables 2, 3, and 4 provide the descriptive statistics (i.e., mean, standard deviation and $\mathrm{P}$ values from statistical test) and frequency distributions for each of the survey items. All of the responses were based on a fivepoint scale with " 1 " being strongly agree, " 2 " agree, "3" neutral, " 4 " disagree, and "5" strongly disagree.

The descriptive statistics and frequency distributions along with p-values related to the survey items, and the ages of the respondents can be seen in Table 2. The table demonstrates three significant and interesting results. First, the survey found that the alternative hypothesis is accepted at the level of alpha $=.05$ that older respondents those 30 to 39 years of age - were more likely to perceive a faculty member's knowledge of the subject matter by the dress/attire they wear in the classroom $(\mathrm{p}$ value $=.036)$. In this case the hypothesis has no effect on older respondents. Similarly, the researchers conclude that the older respondents were also more likely to perceive a faculty member's level of expertise by their dress/attire in the classroom with $\mathrm{p}=.006$. Conversely, the younger respondents - those 17-29 - were likely to perceive a faculty member's concern for the students by what they wear in the classroom, with $\mathrm{p}=.002$. 
Table 2: Descriptive Statistics And Frequency Distributions Related To Age and Survey Items

\begin{tabular}{|c|c|c|c|c|c|c|c|c|c|c|}
\hline & \multicolumn{3}{|c|}{ 17-29 } & \multicolumn{3}{|c|}{ 30-39 } & \multicolumn{3}{|c|}{ Total } & \multirow[b]{2}{*}{$\mathbf{p}$} \\
\hline $\begin{array}{l}\text { A faculty members dress/attire } \\
\text { influences my perception of } \\
\text { his/her... }\end{array}$ & M & $\mathbf{N}$ & SD & $\mathbf{M}$ & $\mathbf{N}$ & SD & $\mathbf{M}$ & $\mathbf{N}$ & SD & \\
\hline Preparation for class & 2.45 & 170 & 1.06 & 2.46 & 28 & 1.00 & 2.44 & 204 & 1.05 & 0.809 \\
\hline Enthusiasm for teaching & 2.82 & 170 & 1.16 & 2.57 & 28 & 1.03 & 2.76 & 204 & 1.16 & 0.077 \\
\hline Knowledge of the subject matter & 3.22 & 170 & 1.17 & 3.32 & 28 & 1.09 & 3.20 & 204 & 1.18 & $0.036^{*}$ \\
\hline Concern for students & 3.38 & 170 & 1.00 & 2.96 & 28 & 1.29 & 3.28 & 204 & 1.07 & $0.002 * *$ \\
\hline $\begin{array}{l}\text { Ability to prepare students for a } \\
\text { successful business career }\end{array}$ & 2.43 & 170 & 1.01 & 2.71 & 28 & 1.12 & 2.45 & 204 & 1.04 & 0.07 \\
\hline Professionalism & 1.80 & 170 & 0.97 & 2.25 & 28 & 1.21 & 1.85 & 204 & 1.01 & 0.063 \\
\hline Credibility & 2.56 & 170 & 1.06 & 2.86 & 28 & 1.01 & 2.59 & 204 & 1.06 & 0.154 \\
\hline Level of expertise & 2.86 & 170 & 1.17 & 3.00 & 28 & 1.28 & 2.84 & 204 & 1.20 & $0.006^{* *}$ \\
\hline $\begin{array}{l}\text { Ability to communicate in the } \\
\text { classroom setting effectively }\end{array}$ & 3.22 & 170 & 1.08 & 3.57 & 28 & 1.07 & 3.25 & 204 & 1.10 & 0.071 \\
\hline Overall performance & 2.91 & 170 & 1.14 & 2.82 & 28 & 1.34 & 2.88 & 204 & 1.17 & 0.296 \\
\hline
\end{tabular}

The descriptive statistics and frequency distributions related to the survey items and gender of the respondents can be seen in Table 3. The survey rendered two significant results related to the gender of the respondents. According to the survey, the female respondents were less likely to view a faculty member's ability to communicate in the classroom setting effectively by their dress/attire, with $p=.004$. Additionally, the survey found that females were less likely to perceive a faculty member's overall performance by his or her dress/attire, with $\mathrm{p}=$ .048 .

Table 3: Descriptive Statistics And Frequency Distributions Related To Gender And Survey Items

\begin{tabular}{|c|c|c|c|c|c|c|c|c|c|c|}
\hline & \multicolumn{3}{|c|}{ Male } & \multicolumn{3}{|c|}{ Female } & \multicolumn{3}{|c|}{ Total } & \multirow[b]{2}{*}{$\mathbf{p}$} \\
\hline $\begin{array}{l}\text { A faculty members } \\
\text { dress/attire influences } \\
\text { my perception of } \\
\text { his/her. . . }\end{array}$ & $\mathbf{M}$ & $\mathbf{N}$ & SD & $\mathbf{M}$ & $\mathbf{N}$ & SD & $\mathbf{M}$ & $\mathbf{N}$ & SD & \\
\hline preparation for class & 2.45 & 92 & 1.05 & 2.43 & 111 & 1.06 & 2.44 & 204 & 1.05 & 0.865 \\
\hline enthusiasm for teaching & 2.77 & 92 & 1.16 & 2.75 & 111 & 1.16 & 2.76 & 204 & 1.16 & 0.968 \\
\hline $\begin{array}{l}\text { knowledge of the subject } \\
\text { matter }\end{array}$ & 3.28 & 92 & 1.21 & 3.14 & 111 & 1.16 & 3.20 & 204 & 1.18 & 0.666 \\
\hline concern for students & 3.40 & 92 & 1.10 & 3.18 & 111 & 1.05 & 3.28 & 204 & 1.07 & 0.33 \\
\hline $\begin{array}{l}\text { ability to prepare students } \\
\text { for a successful business } \\
\text { career }\end{array}$ & 2.53 & 92 & 1.14 & 2.37 & 111 & 0.94 & 2.45 & 204 & 1.04 & 0.467 \\
\hline professionalism & 1.97 & 92 & 1.16 & 1.76 & 111 & 0.87 & 1.85 & 204 & 1.01 & 0.334 \\
\hline credibility & 2.74 & 92 & 1.09 & 2.46 & 111 & 1.03 & 2.59 & 204 & 1.06 & 0.16 \\
\hline level of expertise & 2.82 & 92 & 1.24 & 2.86 & 111 & 1.17 & 2.84 & 204 & 1.20 & 0.963 \\
\hline $\begin{array}{l}\text { ability to communicate in } \\
\text { the classroom setting } \\
\text { effectively }\end{array}$ & 3.53 & 92 & 1.09 & 3.02 & 111 & 1.06 & 3.25 & 204 & 1.10 & $0.004 * *$ \\
\hline overall performance & 3.10 & 92 & 1.24 & 2.69 & 111 & 1.08 & 2.88 & 204 & 1.17 & $0.048^{*}$ \\
\hline
\end{tabular}

The descriptive statistics and frequency distributions related to the survey items and the origin of birth of the respondents can be seen in Table 4. The two categories were "born in the United States" and "born outside the United States". The respondents from Africa and the Caribbean represented $87 \%$ of the population "born outside the United States". These respondents were more likely to perceive a faculty member's professionalism $(\mathrm{mp}=.0004)$ and ability to communicate in the classroom by their attire/dress, with $p=.022$. On the other hand, the respondents born in the United States were more likely to perceive both a faculty member's level of expertise dependent on their dress/attire, with $\mathrm{p}=.037$. 
Table 4: Descriptive And Frequency Distributions Related To Culture And Survey Items

\begin{tabular}{|c|c|c|c|c|c|c|c|c|c|c|}
\hline \multirow{2}{*}{$\begin{array}{l}\text { A faculty members } \\
\text { dress/attire influences } \\
\text { my perception of his/her. } \\
\text {.. }\end{array}$} & \multicolumn{3}{|c|}{ Not Born in America } & \multicolumn{3}{|c|}{ Born in America } & \multirow{2}{*}{$\begin{array}{c}\text { Total } \\
\text { M } \\
\end{array}$} & \multirow[b]{2}{*}{$\mathbf{N}$} & \multirow[b]{2}{*}{ SD } & \multirow[b]{2}{*}{$\mathbf{P}$} \\
\hline & $\mathbf{M}$ & $\mathbf{N}$ & SD & $\mathbf{M}$ & $\mathbf{N}$ & SD & & & & \\
\hline Preparation for class & 2.55 & 56 & 1.11 & 2.40 & 148 & 1.03 & 2.44 & 204 & 1.05 & 0.349 \\
\hline Enthusiasm for teaching & 2.75 & 56 & 1.24 & 2.76 & 148 & 1.13 & 2.76 & 204 & 1.16 & 0.941 \\
\hline $\begin{array}{l}\text { Knowledge of The subject } \\
\text { matter }\end{array}$ & 3.02 & 56 & 1.23 & 3.27 & 148 & 1.15 & 3.20 & 204 & 1.18 & 0.172 \\
\hline Concern for students & 3.16 & 56 & 1.01 & 3.32 & 148 & 1.10 & 3.28 & 204 & 1.07 & 0.332 \\
\hline $\begin{array}{l}\text { Ability to prepare students } \\
\text { for a successful business } \\
\text { career }\end{array}$ & 2.61 & 56 & 1.14 & 2.39 & 148 & 0.99 & 2.45 & 204 & 1.04 & 0.173 \\
\hline Professionalism & 2.18 & 56 & 1.34 & 1.73 & 148 & 0.83 & 1.85 & 204 & 1.01 & $0.004 * *$ \\
\hline Credibility & 2.46 & 56 & 1.04 & 2.64 & 148 & 1.06 & 2.59 & 204 & 1.06 & 0.305 \\
\hline Level of expertise & 2.55 & 56 & 1.24 & 2.95 & 148 & 1.17 & 2.84 & 204 & 1.20 & $0.037 *$ \\
\hline $\begin{array}{l}\text { Ability to communicate in } \\
\text { the classroom setting } \\
\text { effectively }\end{array}$ & 3.54 & 56 & 1.11 & 3.14 & 148 & 1.08 & 3.25 & 204 & 1.10 & $0.022 *$ \\
\hline Overall performance & 2.82 & 56 & 1.35 & 2.90 & 148 & 1.09 & 2.88 & 204 & 1.17 & 0.674 \\
\hline
\end{tabular}

\section{DISCUSSION}

While the survey revealed significant results, the researchers are careful not to generalize as this was a convenience sample. Cultural variations are more of a tentative guideline that demonstrates intercultural interactions and examples in helping to understand nonverbal behavior than a prescription for cultural analysis (Gudykunst \& Matsumoto, 1996). The following discussion addresses the survey results and how age, gender, and culture may influence the degree to which the respondents adopted attitudes toward dress/attire in globally diverse classroom settings and how these factors relate to nonverbal and intercultural communication. Trends in the workforce and in recent intercultural research strongly suggest the need to prepare students for the globalized economy in which success is largely determined by the ability to communicate across cultures. It is important that faculty members begin to diversify teaching and learning strategies and develop communication styles that will increase students' chances of success in today's competitive work environment (Washington \& Okoro, 2009, and Hall \& Berardino, 2006). These communication styles should emphasize effective verbal and nonverbal skills, which include personal appearance and presentations.

\section{Age And Student Perceptions Of Faculty}

Culture within the United States is associated with strength, energy, possibilities and freedom, while age is often associated with declining powers and a loss of respect and authority (Chaney \& Martin; 2007; Gudykunst, 2005). These groups are divided into as many as four distinct generations called traditionalists (those born before 1946), baby boomers (born between 1946 and 1964), generation X (born between 1965 and 1980), and generation Y (born after 1980), all of which have been shaped by different world events and social trends (Bovee \& Thill, 2008). In contrast, many cultures value age and seniority where longevity earns respect and increasing power.

As shown in Figure 1, the older respondents - those 30 -39 years of age (generation X) - were significantly less likely to attribute a faculty member's concern for students to their dress/attire. People born during this period, whether male or female, were perceived as more professional when dressing formal than those that wore any other type of attire. During the same period, the business dress in Canada, England, France, Germany, Japan, and Mexico was similar, with slight variances (Chaney \& Martin, 2007). Since the majority of faculty in the research population dress formally, these results are consistent with the people's standard of dress/attire during that period.

Conversely, the younger respondents - those $17-29$ years of age (generation Y) - were significantly less likely to attribute both a faculty member's knowledge of the subject matter and level of expertise to their dress/attire. 
Dress standards in the U.S. became increasingly casual during the time these respondents were born as did the dress standards in many European companies (Chaney \& Martin, 2007). Again, these results are consistent with the people's standard of dress/attire during that period.

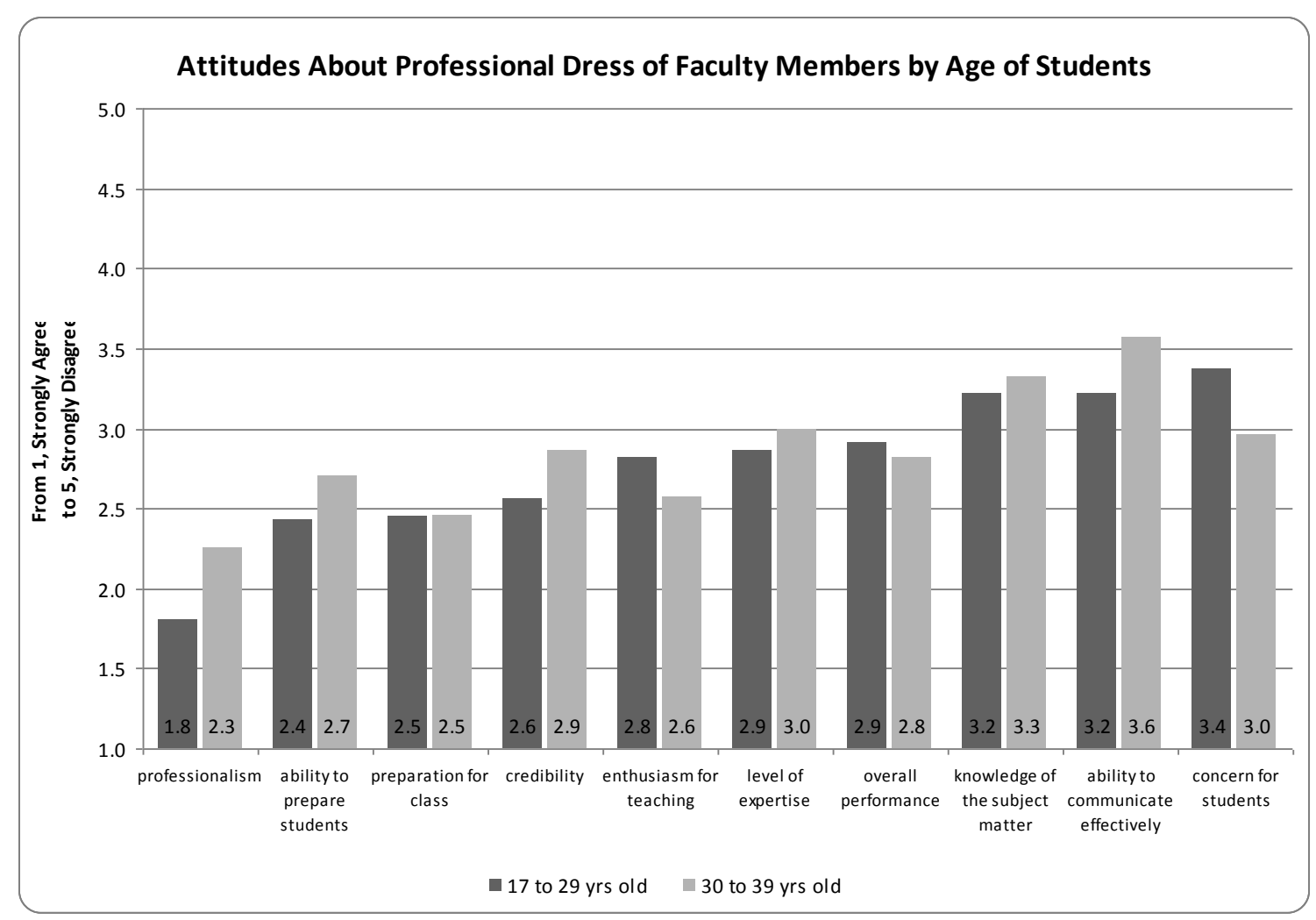

Figure 1

\section{Gender And Student Perceptions Of Faculty}

As reported in the survey, in both cases the male respondents were significantly more likely to attribute a faculty member's ability to communicate effectively and their overall performance with their dress/attire. These results are shown in Figure 2.

In the analysis of these results, we must again remind ourselves of the temptation to stereotype. While current research describes women's communication style as supportive and personal, other research (Messman, Canary \& Hause, 1993) suggests that women's and men's communication styles are more similar than they are different. This may account for this section of the survey reporting the least significant results. In the survey, the male respondents were significantly more likely to attribute a faculty member's ability to communicate in the classroom setting effectively and overall performance with their dress/attire. Another issue that may have affected the results is the disparity in the treatment of men and women in countries other than the United States. Twentyeight percent of the respondents were "born outside the United States". 


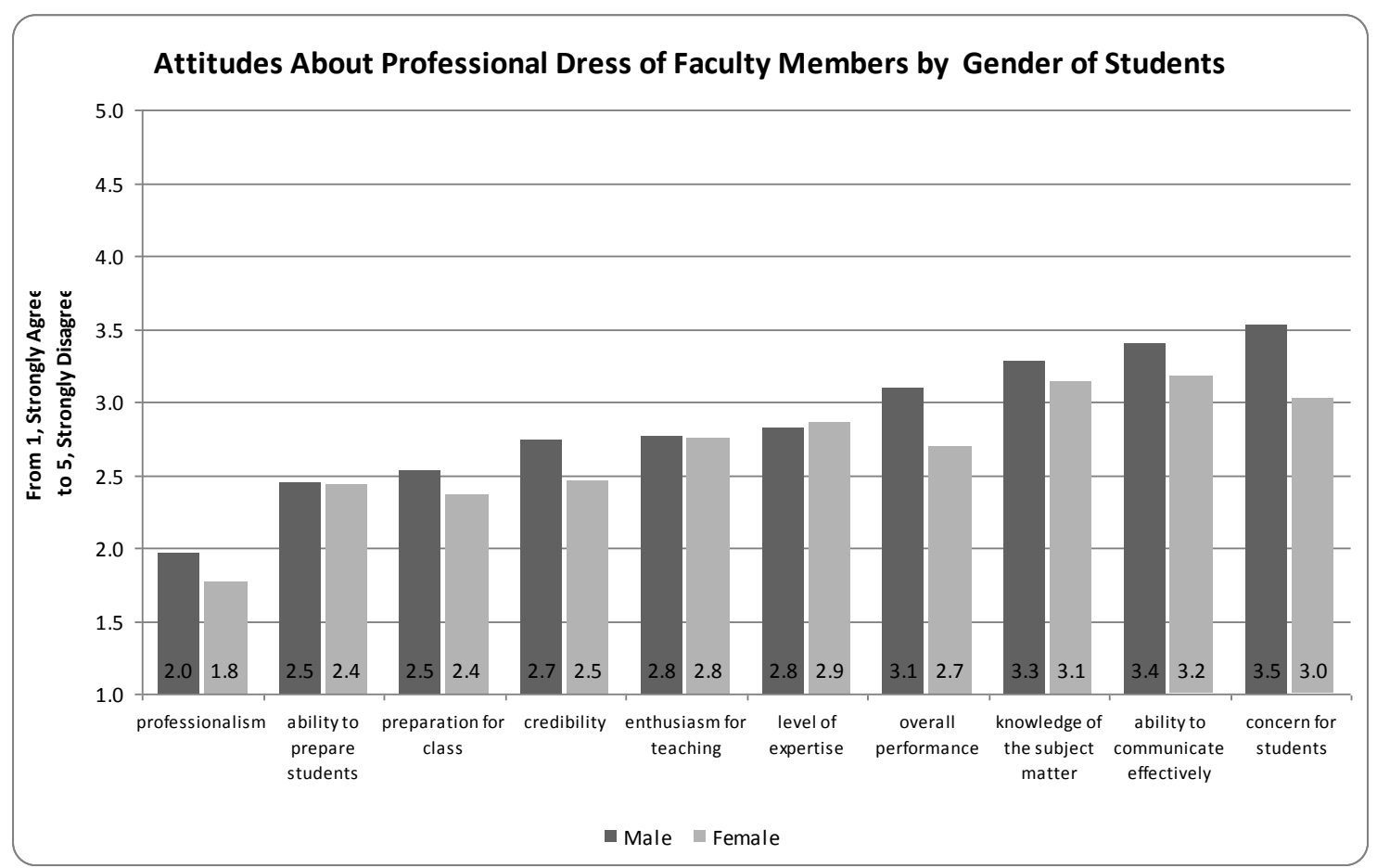

Figure 2

\section{Culture and Student Perceptions of Faculty}

As reported earlier, the respondents "born in the United States" were more inclined to correlate a faculty member's dress/attire with their level of expertise and professionalism. The culture in the United States has related personal appearance with factors such as intelligence and sociability. Conventional wisdom also tells us that others make judgments about people based on their appearance, including everything from hairstyle to body weight, clothing style to skin tone (O'Rourke, 2010). In addition, the United States is at a lower cultural contextual level than the countries represented in the survey as people "born outside the United States". Low context cultures are less flexible than their high context counterparts. Cultural context is the pattern of physical cues, environmental stimuli, and implicit understanding that convey meaning between two members of the same culture (Bovee and Thill, 2008). Hence, the respondents from the United States may have formed early attitudes about how success and professionalism influence the judgments about the personal appearance of a person. A similar case is made for the results showing that the respondents "born outside the United States" reported that they are more likely to judge a faculty member's ability to communicate in the classroom setting effectively by their dress/attire. This reasoning, however, is contrary to how the same respondents judged a faculty member's level of expertise. See Figure 3 for results. 


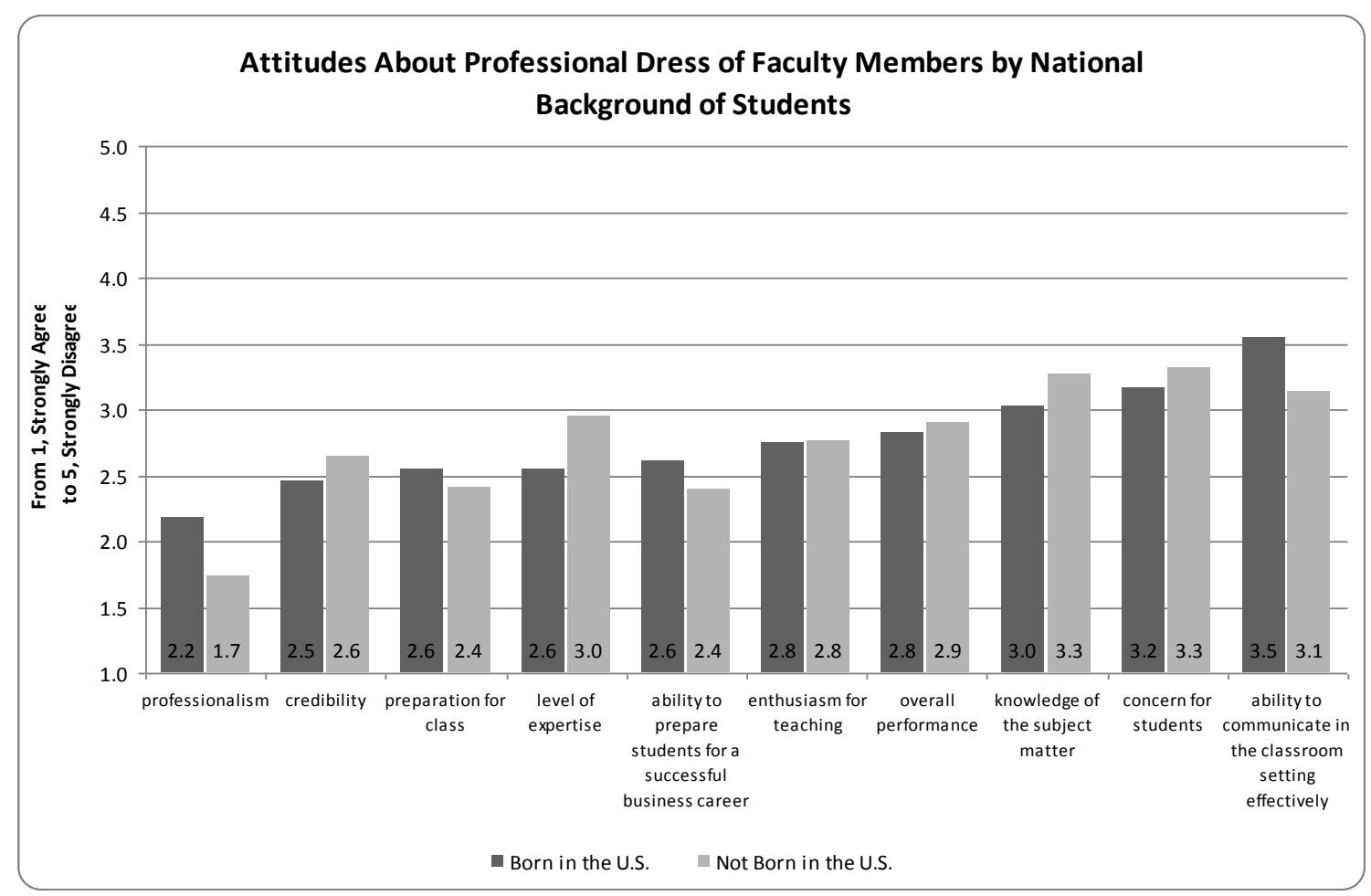

Figure 3

The survey further revealed that respondents "born outside the United States" answered negatively when asked if they judged a faculty member's level of expertise by their dress/attire. If we were to use the same scenario as in the previous case, the conclusion would be polar (directly opposite). The respondents "born outside the United States" were from high-context cultures, but their responses expresse the attitudes of a low-context culture. Lowcontext cultures (United States) take the majority of meaning and information in a verbal code. This style of communication is highly valued where studies often stress not relying on nonverbal and contextual information, such as a person's personal appearance. In the survey, however, the respondents "born outside the United States" reported a significant difference - reporting environmental cues (e.g., personal appearance) - as a factor in determining a faculty member's level of expertise.

Taken together, faculty must become increasingly aware of the vast differences in student values and perceptions in today's classrooms with diverse ages, genders, and cultural backgrounds.

\section{CONCLUSION}

The significance of nonverbal communication within the classroom, in general, and attire of university faculty, in particular, cannot be over-emphasized as a critical part of the learning environment. Moreover, while the merits of professional dress/attire and the perceptions of important attributes of faculty are debatable, the survey results suggest that the phenomenon does influence how students perceive the effectiveness of instructors on several criteria. The results also mirror similar studies based on dress/attire. Thourlby (1978) found that people make key decisions based on clothing, such as level of success and educational background. Another study Malloy (1975) suggests that clothing impacts or influences judgments such as credibility and likeability. This study presented ten evaluation items that the students/ respondents used in rating faculty. Six of these items produced significant results. First, the perception of a faculty member's knowledge of the subject matter, concern for students, and level of expertise were influenced by the age of the respondent. Second, the perception of a faculty member's ability to communicate in the classroom setting effectively and overall performance were impacted by the gender of the respondent. Finally, the respondent's origin of birth influenced the perception of a faculty member's level of 
expertise and professionalism. How students perceived a faculty member's preparation for class, enthusiasm for teaching, ability to prepare students for a successful business career and credibility showed no significant results.

\section{IMPLICATIONS AND FUTURE RESEARCH}

Appropriate attire, while important, is not the single quality that creates student perceptions. It is one of many nonverbal elements that may affect the educational process. As Ting-Toomey (2001) stated, less than 10\% of a message is sent through words, and when verbal and non-verbal messages conflict, the non-verbal message is generally given more consideration. Future research can be utilized to investigate how these elements affect the perception of faculty by students. Teachers can then use these results in practical approaches in improving the instructor-to-student communication and relationship processes. In addition, it is extremely important that faculty recognize the communicative power of their dress/attire in classroom setting. Educators must be mindful of the fact that all which is conveyed in the classroom plays a important part in the educational process, be it spoken or unspoken (Carr, 2006). In addition, as today's university classrooms become increasingly more global, the attitudes and perceptions of the student bodies toward faculty undergo constant change. Faculty must continue to monitor these changes in a constant effort to both keep pace and remain effective in the classroom.

\section{AUTHOR INFORMATION}

Ephraim A. Okoro is an assistant professor of business communication and marketing at Howard University. His research interests probe the interface between intercultural communication and workforce diversity in the context of globalization. Address correspondence to Dr. Ephraim Okoro, Department of Marketing, School of Business, Howard University, 2600 - Sixth Street, NW, Washington, D.C. 20059; email: eaokoro@ howard.edu.

Melvin C. Washington, $\mathrm{PhD}$ is an assistant professor of business and management communication at Howard University. He is the core course coordinator for the business communication program in the School of Business, Department of Marketing. His research focuses on intercultural communication, organizational communication, and critical pedagogy. Address correspondence to Melvin C. Washington, Howard University School of Business, 2600 $6^{\text {th }}$ Street N.W., Washington, D.C. 20059; e-mail: m_c washington@ @oward.edu.

\section{REFERENCES}

1. Barna, L. M. 91977). Stumbling blocks in intercultural communication. In 1. A. Samovar \& R. E. Porter (Eds.), Intercultural Communication ( $8^{\text {th }}$ edition). Belmont, CA: Wadsworth publishing

2. Bassett, R. (1979). Effects of Source Attire on Judgments of Credibility. Central States Speech Journal, 30, 282-285

3. Bovee, C. L., \& Thill, J. V. (2008). Business communication today (9th ed.). Boston: Prentice Hall.

4. Cardon, P., \& Okoro E. (2009, September). Professional characteristics communicated by formal versus casual workplace attire. Business Communication Quarterly. Volume 72, Number 3.

5. Carr, D., Davies, T., \& Lavin, A. (2006). The Effect of Business Faculty Attire on Student Perceptions of the Quality of Instruction and Program Quality. College

6. Chaney, L. H., \& Martin, J. S. (2007). Intercultural Business Communication (4th ed., pp. 191-192). Upper Saddle River, NJ: Pearson Prentice Hall.

7. Check, J. (2001). Positive Traits of the Effective Teacher-Negative Traits of the Ineffective One. Education, 106, 3, 326-334.

8. Elrod, E. (2006). Should teachers wear business attire to school?: NO. NEA Today, 24(5), 45.

9. Gudykunst, W.B. and Young, Y.K. (2003). Communicating with strangers: An Approach to Intercultural Communication. New York: NY: McGraw Hill

10. Gudykunst, W.B. \& Matsumoto, Y. (1996). Cross-cultural variability of communication in personal relationships. In W.B. Gudykunst, S. Ting-Toomey, \& T. Nishida (Eds.), Communication in personal relationships across cultures (pp. 19-56). Thousand Oaks, CA: Sage.

11. Hall, A. \& L. Berardino. (2006). Teaching Professional Behaviors: Differences in the Perceptions of Faculty, Students and Employers. Journal of Business Ethics, 63, 407-415. 
12. Harris, M., James, J. Chavez, J., fuller, M., Kent, S. Massanari, C., \& Wash, F (1983). Clothing:

Communication, Compliance, and choice. Journal of Applied Psychology, 13, 88-97.

13. James, R., \& Devlin, M. (2001). Evaluation of the international student experience 2000: Report prepared for the vice-principal and academic registrar, Melbourne: University of Melbourne.

14. Jandt, F. E. (2001). Intercultural communication: An Introduction ( $3^{\text {rd }}$ edition). Thousand Oaks: Sage publications

15. Martin, J., \& Nakayama, T. (2007). Intercultural communication in contexts (4th ed.). New York: McGraw-Hill. Student Journal, 43(1), 45-55. Retrieved from Academic Search Premier Database.

16. Maslow, A. H. (1970). Motivation and personality, ( $2^{\text {nd }}$ Edition). New York: Harper \& Row.

17. Mehrabian, A. (1968). Communication without Words, Psychology Today, 2, 4, 53-55.

18. Messman, S., Canary, D., \& Hause, K. (2000). Motives to remain platonic, equity, and the use of maintenance strategies in opposite-sex friendships. Journal of Social \& Personal Relationships, 17(1), 67.

19. Molloy, J. (1977). Dress for Success. New York: Warner Books.

20. Molloy, J. (1975). Dress for Success. New York: Warner Books

21. Morris, D. (1977). Manwatching: A Field Guide to Human Behavior. New York: Harry N. Abrams.

22. O'Rourke, IV, J. S. (2010). Management Communication (4thth ed., pp. 280-289). Upper Saddle River, NJ: Pearson Prentice Hall.

23. Rafaeli, \& M. G. Pratt. (1993). Tailored Meanings: On the meaning and Impact of organizational Dress. Academy of Management Review, 18, 32-55.

24. Rollman, S. (1990). Some Effects of teachers' Styles of Dress. Paper presented at the Annual Meeting of the Southern Speech Communication Association, Birmingham, Alabama.

25. Rubin, R., Palmgreen, R., \& Sypher, H. (1994). Communication research measures: A sourcebook. New York: The Guildford Press.

26. Samovar, L. A., \& Porter, R. E. (Eds.). Intercultural communication: A reader (eighth ed.). Belmont, Ca: Wadsworth Publishing Company.

27. Scott, J., O'Neal, J., \& Cheatham, C. (1994). Nonverbal communication and Image Building; their Importance to the Business Professor. Journal of Management Education, 18, 105-110.

28. Slethaung, G. E. (2007). Teaching Abroad: International Education and the Cross-Cultural Classroom. Hong Kong: Hong Kong University Press.

29. Thourlby, W. (1978). You are What You Wear: The key to business success. New York: New American Library.

30. Ting-Toomey, S. \& Oetzel, J. G. (2007). Managing Intercultural Conflict Effectively: Thousand Oaks, CA: Sage Publications, Inc.

31. Washington, M. C., \& Okoro, E. A. (2010). Intercultural Communication in the Classroom: An Analysis of Student Participation and Performance. Washington Business Research Journal, 1(1), 85-100.

32. Wasley, P. (2007). Indiana's Tri-State University Drops Draconian Dress Code and Mohawks Are back. Chronicle of Higher Education, 54(9).

33. Wilson, M.S. \& Hopee, M.H. \& Sayless, L.R. (2002). Managing Across Cultures: A Learning Framework. Greensboro, NC: Center for Creative Leadership.

34. Zweifel, T.D. (2003). Culture Class: Managing the Global High-Performance Team. New York, NY: Swiss Consulting Group, Inc. 
NOTES 